\title{
Effect of Inclusion of Citrus Pulp in the Diet of Finishing Swines
}

\author{
Pedro Henrique Watanabe ${ }^{1 *}$, Maria Cristina Thomaz ${ }^{2}$, Urbano dos Santos Ruiz ${ }^{2}$, Vivian \\ Maia dos Santos ${ }^{2}$, Alessandro Luís Fraga ${ }^{3}$, Leonardo Augusto Fonseca Pascoal ${ }^{1}$, Susana \\ Zaneti da Silva ${ }^{2}$ and Henrique Gonzáles de Faria ${ }^{2}$ \\ ${ }^{1}$ Departamento de Agropecuária; Universidade Federal da Paraíba; 58220-000; Bananeiras - PB - Brasil. \\ ${ }^{2}$ Departamento de Zootecnia; Universidade Estadual Paulista; Via de acesso Prof. Paulo Donato Castellane, s/n; \\ 14884-900; Jaboticabal - SP - Brasil. ${ }^{3}$ In memoriam
}

\begin{abstract}
The aim of this work was to study the effect of inclusion of citrus pulp in the diet of finishing pigs. In the first trial, 16 Topigs barrows with $80.5 \pm 4.7 \mathrm{~kg}$ of initial $\mathrm{BW}$ were used to evaluate the digestibility of citrus pulp. Having $18.85 \%$ of neutral detergent fiber and $41.18 \%$ of neutral detergent soluble fiber, citrus pulp showed as a feasible alternative ingredient to be added in the diets of feed restricted finishing pigs. Second trial tested the use of 0 , 10, $20,30 \%$ of citrus pulp in the diets of 36-feed-restricted barrows with initial BW of $83.7 \pm 5.1 \mathrm{~kg}$. A quadratic trend $(P<0.05)$ as function of citrus pulp levels was observed for daily weight gain and number of experimental days to reach $130 \mathrm{~kg} \mathrm{BW}$, being the best estimated inclusion levels of citrus pulp 10.79 and $10.97 \%$, respectively. For urea and triacylglycerol serological parameters, no effects of citrus pulp were observed $(P>0.05)$, but a quadratic trend existed on cholesterol serological content.
\end{abstract}

Key words: Alternative feedstuffs, Digestibility, Energetic restrictions, Heavy swine, Soluble fiber

\section{INTRODUCTION}

With the improvement of methods for the determination of dietary fibers and the possibility of classification and measurement of the effects of their fractions, fibrous feedstuffs have been reevaluated for feeding swine. An example of this is the inclusion of a source of fiber for feeding breeders to control the excess body weight, to decrease the stress due to confinement, and to be used in the qualitative feed restriction program as well (Gomes et al., 1999). Also, fibrous ingredients have shown good feasibility as source of energy for feeding the finishing swine. In this manner, it is possible to slaughter them with more than $100 \mathrm{~kg} \mathrm{BW}$ but with lower fat deposition, important characteristic taken in system of carcass typification.

The use of fibrous ingredients in the qualitative feed restriction program depends mainly on the cost and availability, conditions present in Brazil. In the world, Brazil is the largest producer of oranges and about $71 \%$ of this is used by the industry (ABECitrus, 2006). Orange processing generates 50 to $70 \%$ of residues (Bampidis and Robinson, 2006), which after drying are called citrus pulp. Although regularly employed as energetic ingredient in the diet of ruminants,

\footnotetext{
*Author for correspondence: pedrowatanabe@cchsa.ufppb.br
} 
utilization of citrus pulp in swine rations has got little attention. Being a residue easily obtained and having high fiber content, citrus pulp could be an excellent ingredient for feeding the finishing swine, subject to a qualitative feed restriction program.

Thus, with the objective of knowing the nutritional value of citrus pulp and its possible use as energetic diluent in pig diet, two trials were conducted. First trial studied the nutrient and energy digestibility of citrus pulp; second one evaluated the effects of inclusion of different citrus levels on performance, number of days to reach $130 \mathrm{~kg} \mathrm{BW}$, and serological parameters of finishing swine subjected to qualitative feed restriction.

\section{MATERIALS AND METHODS}

Two trials were conducted, the first during November through December of 2005, and the second from March to May of 2006.

\section{Trial 1}

In this, sixteen Topigs barrows with $80.5 \pm 4.7 \mathrm{~kg}$ of initial BW purchased from commercial operation were used. The animals were individually allotted in pens equipped with semiautomatic feeders and communicating vessel drinkers. The swine were initially weighed and then designed to two experimental diets:

- Standard ration: with $3400 \mathrm{kcal} \mathrm{DE} / \mathrm{kg}$ as proposed by NRC (1998) to attend requirements for barrows with $80 \mathrm{~kg}$ of $\mathrm{BW}$, high genetic potential for growth, and reared at a room temperature of $24^{\circ} \mathrm{C}$ (Table 1 ).

- Experimental ration: diet composed by $70 \%$ of standard ration plus $30 \%$ of citrus pulp.

Experimental period lasted 14 days, being eight days for adaptation of the animals to the diet, three days to set up the flux of the indicator in the digestive tract, and three days for the collection of faeces. During the eight adjusting days, average feed consumption of two daily meals was taken at $0800 \mathrm{~h}$ and $1700 \mathrm{~h}$. The amount of individually weighed ration was blended with water in a $1: 1$ proportion and furnished to the animals. After 30 min of consumption, the rest of ration was collected and weighed for determination of feed intake. During the adjustment period, when the average daily feed intake was calculated, consumption of ration supplemented with $0.3 \%$ of chromium oxide as indicator was controlled in a way to become its flux evenly distributed in the ingesta.

The amount of ration furnished to each animal in the last six experimental days was the result of the lower coefficient of mean feed intake of adjustment period divided by metabolic weight of the animals. In the last three experimental days, $400 \mathrm{~g}$ of faeces were collected twice daily from rectum of animals after each meal. Faeces were put in blended plastic bags and frozen at $-8^{\circ} \mathrm{C}$ until subsequent analyzes. Finishing collection period faeces were defrosted and then homogenized to compose the samples of each animal. About $200 \mathrm{~g}$ of pooled sample was dried in steam oven at $65^{\circ} \mathrm{C}$ for $72 \mathrm{~h}$ and milled in a knife-type mill to pass a 1mm screen.

Processed samples of faeces and ration were analyzed for dry matter (DM), mineral matter (MM), acid detergent fiber (ADF), starch, crude protein $(\mathrm{CP})$, calcium and phosphorus according to Silva and Queiroz (2002), as well as neutral detergent fiber (NDF) by Van Soest et al. (1991) method, neutral soluble detergent fiber (NSDF) according to Hall et al. (1998), chromium oxide level by Fenton and Fenton (1979) method, and crude energy in Parr-type calorimetric bomb.

From these results, apparent digestibility coefficients of DM, MM, starch, NDF, ADF, NSDF, CP, CE, calcium and phosphorus, and levels of nutrients and $\mathrm{DE}$ of citrus pulp were calculated according to equations described by Matterson et al. (1965).

\section{Trial 2}

In trial 2, 36 Topigs barrows of high capacity of lean deposition with $80.4 \pm 2.7 \mathrm{~kg}$ of initial BW were allotted in individual pigpens of $2.55 \mathrm{~m}^{2}$, each one equipped with semi-automatic feeders and communicating vessel drinkers. Increasing levels of citrus pulp were added in the diets of animals distributed in four treatment groups during five days of adjustment before reaching the total amount of citrus pulp established in trial protocol. Afterward, the experimental period started with barrows weighing $83.7 \pm 5.1 \mathrm{~kg}$ on average. Diets (Table 2) were formulated to attend the requirements for barrows with $105 \mathrm{~kg} \mathrm{BW}$, high genetic potential for growth, and reared at room temperature of $24^{\circ} \mathrm{C}$ as proposed by NRC (1998). The values of $\mathrm{ED}$ and $\mathrm{Ca}$ of citrus pulp considered to formulate the diets were obtained in trial 1 . 
Table 1 - Proximal and calculated compositions of standard ration.

\begin{tabular}{|c|c|}
\hline Feedstuffs, \% & Standard ration \\
\hline Corn & 73.94 \\
\hline Soy meal & 24.10 \\
\hline Citrus pulp & - \\
\hline Limestone & 0.80 \\
\hline Dicalcium phosphate & 0.46 \\
\hline Salt & 0.30 \\
\hline Vitamin-mineral premix ${ }^{(1)}$ & 0.40 \\
\hline Total & 100.00 \\
\hline \multicolumn{2}{|l|}{ Calculated composition $^{(2)}$} \\
\hline Digestible Energy, $\mathrm{kcal} / \mathrm{kg}$ & 3411 \\
\hline Crude Protein, $\%$ & 17.65 \\
\hline NDF - Neutral Detergent Fiber, $\%^{(3)}$ & 9.46 \\
\hline ADF - Acid Detergent Fiber, $\%^{(3)}$ & 2.01 \\
\hline NDSF - Neutral Detergent Fiber, $\%^{(3)}$ & 7.84 \\
\hline Starch, $\%^{(3)}$ & 44.71 \\
\hline Digestible Lys, \% & 0.78 \\
\hline Digestible Met + Cys, \% & 0.53 \\
\hline Calcium, $\%$ & 0.52 \\
\hline Non-phytate phosphorus, $\%$ & 0.17 \\
\hline \multicolumn{2}{|c|}{$\begin{array}{l}\text { Vitamin premix - amount per } \mathrm{kg} \text { of product: } 2,500,000 \mathrm{UI} \text { vitamin A, 500,000 UI vitamin D3, } 50 \mathrm{mg} \text { biotin, } 50 \mathrm{mg} \text { choline } \\
10000 \mathrm{mg} \text { niacin, } 3000 \mathrm{mg} \text { calcium pantotenate, } 7 \mathrm{mg} \text { vitamin B12, } 1800 \mathrm{mg} \text { vitamin B2, } 7500 \mathrm{mg} \text { vitamin E, } 1000 \mathrm{mg} \text { vitami } \\
\mathrm{K} 3 . \text { Mineral premix - amount per kg of product: } 40,000 \mathrm{mg} \mathrm{Fe}, 35,000 \mathrm{mg} \mathrm{Cu}, 20,000 \mathrm{mg} \mathrm{Mn}, 40,000 \mathrm{mg} \mathrm{Zn,} 360 \mathrm{mg} \mathrm{Co,} 840 \\
\mathrm{mg} \text { I, } 120 \mathrm{mg} \text { Se. } \\
2 \text { Nutritional compositions according to Rostagno et al (2005). } \\
{ }^{3} \text { Analyzed values. }\end{array}$} \\
\hline
\end{tabular}

Table 2 - Proximal and calculated compositions of experimental diets.

\begin{tabular}{|c|c|c|c|c|}
\hline \multirow{2}{*}{ Feedstuffs, \% } & \multicolumn{4}{|c|}{ Diet } \\
\hline & Control & Cp10 ${ }^{(1)}$ & Cp20 ${ }^{(1)}$ & $\mathrm{Cp30}^{(1)}$ \\
\hline Corn & 81.78 & 71.01 & 60.24 & 49.43 \\
\hline Soy meal & 16.40 & 17.17 & 17.94 & 18.75 \\
\hline Citrus pulp & 0.00 & 10.00 & 20.00 & 30.00 \\
\hline Limestone & 0.58 & 0.58 & 0.57 & 0.57 \\
\hline Dicalcium phosphate & 0.64 & 0.64 & 0.65 & 0.65 \\
\hline Salt & 0.30 & 0.30 & 0.30 & 0.30 \\
\hline Vitamin-mineral premix ${ }^{(2)}$ & 0.30 & 0.30 & 0.30 & 0.30 \\
\hline Total & 100.00 & 100.00 & 100.00 & 100.00 \\
\hline \multicolumn{5}{|l|}{ Calculated composition $^{(3)}$} \\
\hline Digestible energy, $\mathrm{kcal} / \mathrm{kg}$ & 3391 & 3294 & 3197 & 3100 \\
\hline Crude protein, $\%$ & 14.87 & 14.28 & 14.37 & 14.48 \\
\hline NDF, $\%^{(4)}$ & 11.88 & 12.61 & 13.33 & 14.06 \\
\hline $\mathrm{ADF}, \%(4)$ & 4.23 & 5.35 & 6.46 & 7.57 \\
\hline NDSF, $\%^{(4)}$ & 7.41 & 10.95 & 14.63 & 18.04 \\
\hline Starch, \%(4) & 54.91 & 48.34 & 41.76 & 35.17 \\
\hline Digestible Lys, \% & 0.58 & 0.58 & 0.58 & 0.58 \\
\hline Digestible Met + Cys, \% & 0.46 & 0.43 & 0.41 & 0.38 \\
\hline Calcium, \% & 0.44 & 0.44 & 0.44 & 0.44 \\
\hline Non-phytate phosphorus., $\%$ & 0.18 & 0.18 & 0.17 & 0.17 \\
\hline
\end{tabular}

${ }^{1}$ Citrus pulp at 10, 20, and $30 \%$ of inclusion.

2 Vitamin premix - amount per kg of product: 2,500,000 UI vitamin A, 500,000 UI vitamin D3, 50 mg biotin, 50 mg choline, $10000 \mathrm{mg}$ niacin, $3000 \mathrm{mg}$ calcium pantotenate, $7 \mathrm{mg}$ vitamin B12, $1800 \mathrm{mg}$ vitamin B2, $7500 \mathrm{mg}$ vitamin E, $1000 \mathrm{mg}$ vitamin K3. Mineral premix - amount per kg of product: 40,000 mg Fe, 35,000 mg Cu, 20,000 mg Mn, 40,000 mg Zn, 360 mg Co, 840 $\mathrm{mg} \mathrm{I}, 120 \mathrm{mg} \mathrm{Se}$.

${ }^{3}$ Nutritional compositions according to Rostagno et al (2005).

${ }^{4} \mathrm{NDF}=$ Neutral Detergent Fiber; ADF = Acid Detergent Fiber; NDSF = Neutral Detergent-Soluble Fiber. Analyzed values. 
Experimental treatments were:

- Control diet - corn-soy diet without citrus pulp;

- Cp10 diet - formulated to have the same level of digestible Lys, $\mathrm{Ca}$ and non-phitate $\mathrm{P}$ of control diet, and $10 \%$ of citrus pulp;

- Cp20 diet - formulated to have the same level of digestible Lys, $\mathrm{Ca}$ and non-phytate $\mathrm{P}$ control diet, and $20 \%$ of citrus pulp;

- Cp30 diet- formulated to have the same level of digestible Lys, $\mathrm{Ca}$ and non-phytate $\mathrm{P}$ levels of control diet, and $30 \%$ of citrus pulp.

Animals had free access to water and feed along all experimental period. Rest of ration and BW of animals were weighed on daily and weekly bases, respectively. Daily feed intake (DFI), daily weight gain (DWG), and feed:gain ratio (FGR) were calculated along all experimental period. Final 130 $\mathrm{kg} \mathrm{BW}$ was the target weight to remove the animals from the trial and slaughter them.

Total feed intake was obtained by the sum of weekly consumptions measured during the entire experimental period. The number of estimated experimental days to reach $130 \mathrm{~kg}$ of BW (D130) was based on initial weight and calculated as following:

$\mathrm{D} 130=(130-$ initial weight $) / \mathrm{DWG}_{\text {total period }}$

Where:

$\mathrm{DWG}_{\text {total period }}=($ final weight - initial weight $) /$ number of experimental days

The animals were slaughtered day-after the last weighing (final weight) and after $15 \mathrm{~h}$ of solid fasting period. Before slaughtering the animals, they were re-weighed for the determination of postfast weight. Losses of fast weights (FWL), as percent, were calculated by the following formula:

$\mathrm{FWL}=[($ final weight - postfast weight $) /$ final weight] x 100

\section{Serological parameters}

Two samples of the blood of each experimental unit were taken, one in starting period and the other a day before slaughtering and fasting period. Blood was taken by cranial vein puncture, and immediately collected in a tube without anticoagulant. The blood was centrifuged at 3500 rpm for $15 \mathrm{~min}$ and the serum destined to dose urea, triacylglycerol and total cholesterol contents, using commercial reagent kits.

\section{Statistical analyses}

A randomized block design was used in the both trials to control the differences in initial weight. Two treatments (standard and test diets) with eight replicates of one animal each were evaluated in trial 1. Trial 2 tested four treatments with nine replicates of one animal each. For urea, tryacylglicerol and total cholesterol evaluations, initial measurement of each respective parameter served as covariate in the statistical model. Data obtained were tested for homogeneities of variances among treatments before ANOVA using SAS statistical software (SAS, 1998).

\section{RESULTS AND DISCUSSION}

\section{Trial 1}

Table 3 presents the coefficients of digestibility of dry matter (DCDM), mineral matter (DCMM), neutral detergent fiber (DCNDF), acid detergent fiber (DFADF), neutral soluble detergent fiber (DCNSDF), starch (DCstarch), crude protein (DCCP), crude energy (DCCE), calcium (DCcalcium), phosphorus (DCphosphorus), and contents of digestible protein (DP) and digestible energy (DE) of standard and experimental rations. Comparing the rations, it was observed that the inclusion of citrus pulp in the standard diet significantly altered the coefficients of digestibility of all the nutrients and energy, except mineral matter. In the program of qualitative feed restriction, inclusion of fibrous ingredients to diets should be first evaluated to check the possible negative effects upon the digestibilities of nutrients and energy. Nadai (2003), in an evaluation of the inclusion of $20 \%$ of rice hulls to diet of feed restricted swine, observed that noble feedstuffs as corn and soy meal were underutilized. In this study, diet with citrus pulp at $30 \%$ in substitution to same amount of standard ration promoted a reduction of 28.0 and $7.5 \%$ on the digestibility of protein and energy, respectively.

Chemical composition of citrus pulp is shown in Table 4.

According to results, citrus pulp presented high coefficient of digestibility of the dry matter (72.6\%), probably due to its high content of soluble fiber, passive of higher fermentation. Fiber 
effects on feed digestibility were different and consistent with the solubility of their components. While Bach Knudsen et al. (1993) found inverse correlation between the proportion of crude fiber (insoluble) and the digestibility of the diet due to the higher digesta passage rate with consequent lower fermentation period, Dierick et al. (1989) observed that this relation was not applicable for ingredients rich on soluble fiber, as alfalfa, soy hulls, wheat meal, and beet pulp, probably as consequence of high fermentability of these sources.
The starch, a polysaccharide widely present in cereal grain, is the main source of energy for monogastric animals, providing glucose by hydrolyses. Citrus pulp has low level of starch (3.44\%) as compared to corn (60.0\%) according to Rostagno et al. (2005), but they both have high digestibility of nutrients. Coefficients of digestibility of NDF and ADF of citrus pulp here tested were low, 40.05 and $46.44 \%$, respectively, but DCNSDF was high (85.93\%).

Table 3 - Coefficients of digestibility (DC), and content of digestible protein (DP) and digestible energy (DE) of standard and experimental rations of heavy swine.

\begin{tabular}{lcccc}
\hline DC $(\%)$ & Standard ration & Experimental ration & CV \% & P \\
\hline DC DM & 87.89 & 83.60 & 0.68 & 0.0001 \\
DC MM & 39.07 & 37.99 & 8.39 & 0.1807 \\
DC NDF & 61.36 & 66.25 & 2.83 & 0.0256 \\
DC FDA & 42.53 & 50.77 & 8.31 & 0.0186 \\
DC NDSF & 87.13 & 85.48 & 7.90 & 0.0322 \\
DC starch & 99.51 & 99.19 & 0.19 & 0.0001 \\
DC CP & 85.26 & 75.23 & 2.14 & 0.0004 \\
DC CE & 87.89 & 83.01 & 0.87 & 0.0002 \\
DC Ca & 37.60 & 34.23 & 6.80 & 0.0030 \\
DC P & 19.88 & 28.01 & 9.10 & 0.0032 \\
DP (\%) & 14.17 & 10.18 & - & - \\
DE (kcal/kg) & 3335 & 3083 & - & - \\
\hline
\end{tabular}

Table 4 - Chemical composition and content of digestible nutrient and digestible energy of citrus pulp.

\begin{tabular}{lccc}
\hline $\begin{array}{c}\text { Nutrient and } \\
\text { energy }\end{array}$ & Chemical composition & $\begin{array}{c}\text { Coefficient of digestibility, } \\
\text { \% }\end{array}$ & $\begin{array}{c}\text { Digestible Nutrients and } \\
\text { Digestible Energy }\end{array}$ \\
\hline DM (\%) & 89.10 & 72.60 & 64.69 \\
MM (\%) & 7.88 & 36.83 & 2.90 \\
NDF $(\%)$ & 18.85 & 40.05 & 7.55 \\
ADF $(\%)$ & 14.32 & 46.44 & 6.65 \\
NDSF $(\%)$ & 41.18 & 85.93 & 35.39 \\
Starch (\%) & 3.44 & 89.49 & 3.07 \\
CP $(\%)$ & 6.35 & 13.98 & 0.89 \\
DE (kcal/kg) & 3528 & 70.75 & 2496 \\
Ca (\%) & 1.670 & 0.520 & 0.009 \\
P (\%) & 0.750 & 0.310 & 0.002 \\
\hline
\end{tabular}

Finishing swine have a fully developed digestive system, with potential to degrade the diverse fiber components, mainly in the cecum. Nevertheless, those components show different fermentability capacities by the microbiota of digestive tract. Thus, pectin, an important compound of citrus pulp fiber, is highly fermentable, and being soluble shows high coefficient of digestibility, this was confirmed by the high DCNSDF here observed (Table 4). On the other hand, insoluble fractions, measured by NDF and ADF analyses, and composed by insoluble hemi-cellulose; cellulose and lignin (Dierick et al., 1989) of low fermentation in the digestive tract of swine shown low digestibilities.

Citrus pulp presented a CP level of $6.35 \%$, but its coefficient of digestibility was only $13.98 \%$. These values differed from those presented at Rostagno et al. (2005), where correspondent values were $55.0 \% \mathrm{DCCP}$ and $3.5 \% \mathrm{DP}$. 
Protein bounded by insoluble fiber is hardly degraded in the digestive tract; as a consequence, its availability for the animal is very low. On the ohter hand, soluble fibers composed by the soluble portion of hemi-cellulose; gums and mucilage (Southgati and Englyst, 1985) determine an increase on viscosity of digesta, lowering the enzymatic action on dietetic protein. Besides, those compounds serve as substrate for microbial fermentation in the cecum (Johnston et al., 2003), increasing endogenous nitrogen losses, and lowering the protein digestibility (Etiene, 1987; Jansmann et al., 2002).

As citrus pulp has a fermentative potential, its energetic value for feeding the finishing swine should be considered. Brazilian Tables of Feedstuff Composition (Rostagno et al., 2005) register higher digestible energy content (2956 vs $2496 \mathrm{kcal} / \mathrm{kg}$ ) than here observed. For the evaluation of high-soluble-fiber ingredient showing fermentative potential, results of nutritional values by ileal digestibility determination that exclude the process of cecal degradation should be the method of choice, as the products obtained from the microbial fermentation would have low rates of utilization for the swine (Batterham, 1991).

High calcium content of citrus pulp occurs in consequence of the limestone inclusion on its processing and dying. Total calcium levels of citrus pulp here observed $(1.67 \%)$ was similar to those $(1.57 \%)$ presented at Brazilian Tables of Feedstuff Compositions (Rostagno et al., 2005). However, as the use of limestone with high level of impurities from siderurgical industries is usual practice to dry citrus pulp (Polpa, 1998), this ingredient contains low level of available calcium $(0.009 \%)$. Thus, for formulation of swine diets with inclusion of citrus pulp available calcium instead of total calcium should be considered in order to assure an adequate supply of minerals. The important functions of calcium on the maintenance of bone tissue, blood coagulation, and energy metabolism result in great requirement of this mineral for finishing swine. An inadequate level on diets can determine poor development and bone fracture due to the high weight of those animals (Penz Júnior and Viola, 1998). Low coefficient of digestibility was observed for phosphorus $(0.31 \%)$, probably due to the complex formation between the mineral and fibrous components or phytic acid of the ingredient.

\section{Trial 2}

Table 5 and Figure 1 present the performance data (daily feed intake, daily weight gain, and feed:gain ratio), total feed intake, final weight, post-fast weight, fast weight loss and estimated days to reach $130 \mathrm{~kg} \mathrm{BW}$, as well as the prediction equations as function of citrus pulp levels in experimental diets. Dietary levels of citrus pulp did not affect the daily feed intake. In spite of its low palatability (Domínguez, 1995), swine adapted to the new ingredient of the diets even on the highest level of inclusion. It is known that swine increase daily feed intake when a progressive dilution of the ration with inert or indigestible material is done (Chadd, 1990; Lee et al., 2002), this was different the results observed here, where no intake counterbalance occurred. In spite of the presence of substances that decreased the palatability, the high water retention capacity of citrus pulp could maintain the physical satiate for longer time, lowering the stimulus to feed (Kyriazakis and Emmans, 1995). However, Chadd (1990), diluting a high digestible energy diet (3500 $\mathrm{kcal} / \mathrm{kg}$ ) with progressive addition of oat to reach $2300 \mathrm{kcal} / \mathrm{kg}$ for feeding $120-\mathrm{kg}$ BW swine, observed an increase in feed intake as the level of energy decreased up to $2500 \mathrm{kcal} / \mathrm{kg}$. He concluded that the lowest level of digestible energy promoted a decrease in feed intake without any compensation of this low digestible energy level provided by the bulky diet.

In the present trial, besides energetic dilution of the diet with the inclusion of citrus pulp a decrease on daily feed intake was expected for physical limitation of intestinal tract due to the high capacity of water retention and the characteristic of its soluble fractions, but this did not occur. Dietetic levels of citrus pulp did not affect $(\mathrm{P}>0.1)$ the feed:gain ratio, total feed intake, final weight, post-fast weight, and fast-loss weight.

A quadratic trend $(\mathrm{P}=0.0157)$ for daily weight gain was observed, being the highest gain obtained with the inclusion of citrus pulp at $10.79 \%$ (Fig. 1a). This level of inclusion was the same observed for the best D130, confirming the former result. 
Table 5 - Mean values and coefficients of variation (CV) of performance data, feed consumption, estimated number of experimental days to reach $130 \mathrm{~kg} \mathrm{BW}$-body weight (D130), final and post fast BW, and loss of weight on fast period of pigs fed different levels of citrus pulp.

\begin{tabular}{|c|c|c|c|c|c|c|c|}
\hline \multirow{2}{*}{ Characteristics } & \multicolumn{4}{|c|}{ Level of citrus pulp, \% } & \multirow{2}{*}{$\mathrm{CV}, \%$} & \multirow{2}{*}{ Regression } & \multirow{2}{*}{$\mathbf{P}$} \\
\hline & $\mathbf{0}$ & 10 & 20 & 30 & & & \\
\hline Daily feed consumption, $\mathrm{kg}$ & 3.17 & 3.25 & 3.12 & 2.87 & 9.64 & - & 0.07 \\
\hline Daily weight gain, $\mathrm{kg}$ & 0.90 & 0.94 & 0.92 & 0.79 & 11.27 & Quadratic & 0.0157 \\
\hline Feed:gain ratio & 3.52 & 3.49 & 3.39 & 3.64 & 7.77 & - & $>0.1$ \\
\hline Total feed consumption, $\mathrm{kg}$ & 160.60 & 158.50 & 157.00 & 170.50 & 11.40 & - & $>0.1$ \\
\hline Final weight, kg & 129.60 & 129.40 & 130.50 & 129.60 & 1.53 & - & $>0.1$ \\
\hline Post-fast weight, kg & 128.80 & 128.50 & 129.10 & 128.50 & 1.74 & - & $>0.1$ \\
\hline Weight loss on fast period, $\mathrm{kg}$ & 0.85 & 1.03 & 1.06 & 1.03 & 37.40 & - & $>0.1$ \\
\hline D130, days & 51.50 & 49.40 & 49.70 & 60.50 & 11.60 & Quadratic & 0.0037 \\
\hline
\end{tabular}



a



b

Figure 1 - Daily weight gain (a), and experimental days to reach $130 \mathrm{~kg} \mathrm{BW}$ (b) as function of citrus pulp levels.

Serological parameters and prediction equations for cholesterol levels as functions of citrus pulp levels are indicated in Table 6 and Figure 2, respectively. Inclusion of citrus pulp to diets did not decrease the blood triacylglycerol content, as the highest reduction of energy was $8.5 \%$, which was observed with the use of $\mathrm{Cp} 30$ diet. However, Fraga et al. (2008) observed a negative linear trend on triacylglycerol levels as the energy of diet drop up to $20 \%$ with the inclusion of rice hulls. For the total cholesterol content, a quadratic trend was observed, and the highest predicted level was reached at $22.63 \%$ of citrus pulp inclusion. (Fig. 2).

Many studies with monogastric animals, including humans, have demonstrated reduction in the levels of serum cholesterol and cholesterol-related composts with the use of fibrous diets (Ludwig et al., 1999), and the most efficient reducer was the soluble fibers (Delaney et al., 2003). One of the hypotheses for this effect is the capacity of some fiber constituents for adsorbing the steroids and derived composts, including bile salts and cholesterol, which are excreted through faeces. For reposition of excreted bile, an increase in hepatic cholesterol synthesis may be necessary (Kreuzer et al., 2002).

Pectin is one of fiber compounds that potentially functions as cholesterolemic reducer (StasseWolthuis et al., 1980). But a quadratic trend on serum cholesterol content as dietary citrus levels increased was observed in the present trial. Kreuzer et al. (2002), studing the effects of fermentable fibrous compounds (hemicellulose and pectin) on the levels of serum cholesterol, observed that pectin was the most efficient hypocholesterolemic fiber fraction. According to Kreuzer et al. (1991), the fiber effect in the intestine, lowering the absorptive process of cholesterol and bile salts, is not only mediated by pectin-adsorption capacity, but the action of microflora must be also considered. Since pectin is 
soluble and rapidly digestible as compared to hemicelluloses, pectin-adsorbed-cholesterol and bile salts are discharged before the end of small intestine of swine where absorption could take place. Only when citrus pulp was added at a level where cholesterol adsorption capacity by its fibrous fraction was higher than the rate of degradation of the same fraction (Fig. 2), a decrease in total serum cholesterol level was observed.

Table 6 - Mean values and coefficients of variation (CV) of serological parameters of initial (IS) and final (FS) blood samples of pigs fed different levels of citrus pulp.

\begin{tabular}{|c|c|c|c|c|c|c|c|c|}
\hline \multirow{3}{*}{$\begin{array}{c}\text { Serological } \\
\text { parameters, } \mathbf{m g} / \mathrm{dL}\end{array}$} & \multirow{3}{*}{ IS } & \multicolumn{4}{|c|}{ FS } & \multirow{3}{*}{$\mathrm{CV}, \%$} & \multirow{3}{*}{ Regression } & \multirow{3}{*}{$\mathbf{P}$} \\
\hline & & \multicolumn{4}{|c|}{ Level of citrus pulp, \% } & & & \\
\hline & & $\mathbf{0}$ & 10 & 20 & 30 & & & \\
\hline Triacylglycerol & 37.86 & 45.74 & 52.01 & 60.97 & 56.29 & 31.54 & & $>0.1$ \\
\hline Total cholesterol & 117.80 & 98.29 & 128.67 & 142.25 & 140.41 & 18.88 & Quadratic & 0.0001 \\
\hline Urea & 27.89 & 27.72 & 29.66 & 23.98 & 32.54 & 35.33 & - & $>0.1$ \\
\hline
\end{tabular}

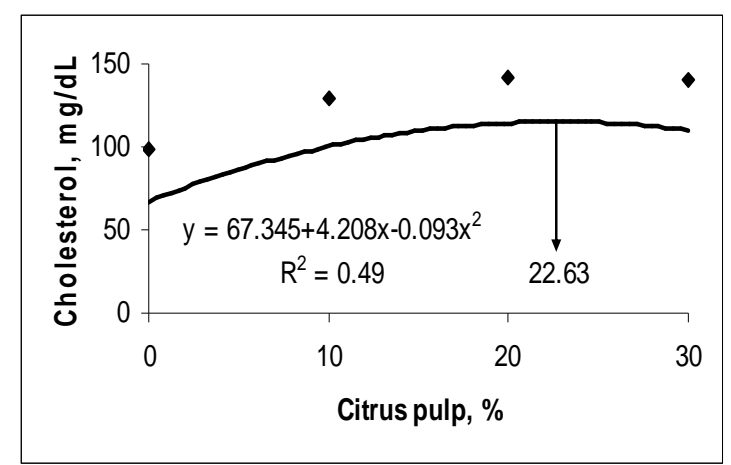

Figure 2 - Total cholesterol content of serum as function of citrus pulp levels.

As a consequence of the small reduction in energy intake, increase of amino acid catabolism did not occur, as indicated by the lack of effect of dietary citrus pulp level upon serum urea content.

The citrus pulp nutritional characteristics did not limit its use in finishing swine feeding and could be used in the rations at the level of $10.0 \%$. Nevertheless, for the formulation of diets with this, available calcium content should be considered instead of total calcium level.

\section{RESUMO}

No primeiro ensaio foram utilizados 16 suínos machos castrados da linhagem Topigs, com peso inicial de $80,5 \pm 4,7 \mathrm{~kg}$, para a avaliação biológica da polpa cítrica. Por apresentar $18,85 \%$ de fibra em detergente neutro e $41,18 \%$ de fibra solúvel em detergente neutro, a polpa cítrica mostrou-se como um ingrediente viável a ser utilizado em programas de restrição alimentar qualitativa. No segundo ensaio foram utilizados 36 suínos machos castrados, com peso inicial de $83,7 \pm 5,1 \mathrm{~kg}$, recebendo rações com níveis de $0,10,20$ e $30 \%$ de polpa cítrica. Os animais foram abatidos com peso próximo de $130 \mathrm{~kg}$, sendo avaliados quanto ao desempenho e parâmetros séricos. Houve resposta quadrática $(\mathrm{P}<0,05)$ para ganho diário de peso e número de dias para atingir o peso de $130 \mathrm{~kg}$, em função dos níveis de polpa cítrica na dieta, sendo observados melhores resultados com níveis de inclusão de 10,79 e 10,97\%, respectivamente. Para os parâmetros séricos avaliados, não foi observado efeito $(\mathrm{P}>0,05)$ dos níveis de polpa cítrica sobre a uréia e triacilgliceróis, porém houve resposta quadrática $(\mathrm{P}<0,05)$ para o colesterol em função dos níveis de polpa cítrica.

\section{REFERENCES}

Associação Brasileira de Exportadores de Cítricos (ABECitrus). (2006), Subprodutos da laranja. Available in: www.abecitrus.com.br/subprodutos_br.html\#oessenci ais. Acess on: 18 out. 2006. 
Bach Knudsen, K. E.; Jensen, B. B.; Hansen J. (1993), Digestion of polysaccharides and other major components in the small and large intestine of pigs fed on diets consisting of oat fractions rich in beta-Dglucans. Br. J. Nutr., 70, 537-556.

Bampidis, V. A.; Robinson, P. H. (2006), Citrus byproducts as ruminant feeds: A review. Anim. Feed Sci. Technol., 128, 175-217.

Batterham, E. S. (1991), Protein and energy relationships for growing pigs. In: Principles of pig science, ed. Cole, D. J. A.; Wiseman, J.; Varley, M. A. Nottingham University Press: Loughborough, pp. 107-121.

Chadd, S. A. (1990), Voluntary feed intake of hybrid pigs. $\mathrm{PhD}$ Thesis, University of Nottingham, Nottingham,.

Delaney, B.; Nicolosi, R. J.; Wilson, T. A.; Carlson, T.; Frazer, S.; Zheng, G. H.; Hess, R.; Ostergren, K.; Harworth, J.; Knutson, N. (2003), Beta-glucan fractions from barley and oats are similarly antiatherogenic in hypercholesterolemic syrian golden hamsters. J. Nutr., 133, 468-495.

Dierick, N. A., Vervaeke, I.J.; Demeyer, D. I.; Decuypere, J. A. (1989), Approach to the energetic importance of fibre digestion in pigs. I. Importance of fermentation in the overall energy supply. Anim. Feed Sci. Technol, 23, 141-167.

Domínguez, P. L. (1995), Pulpa de cítricos en la alimentación de cerdos. Revista Computadorizada de Producción Porcina, 2.

Etienne, M. (1987), Utilization of high fibre and cereal by sow. A review. Livest. Prod. Sci., 16, 229-241.

Fenton, T. W.; Fenton, M. (1979), An improved procedure for determination of chromic oxide in feed and feces. Can. J. Anim. Sci., 59, 631-634.

Fraga, A. L.; Thomaz, M. C.; Kronka, R. N.; Budiño, F. E. L.; Malheiros, E. B. (2008). Restrição alimentar qualitativa para suínos com elevado peso de abate. $R$. Bras. Zootec., 37, 869-875.

Gomes, J. D. F.; Sobral, P. J. A.; Gomide, C. A. (1999), Efeitos do incremento de fibra em detergente neutro sobre desempenho e características de carcaça de suínos em fase de crescimento-terminação. Paper presented at $35^{\text {th }}$ Reunião Anual da Sociedade Brasileira de Zootecnia. SBZ, Porto Alegre, Brasil.

Hall, M. B.; Pell, A. N.; Chase, L. E. (1998), Characteristics of neutral detergent-soluble fiber fermentation by mixed ruminal microbes. Anim. Feed Sci. Technol, 70, 23-39.

Jansmann, A. J. M.; Smink, W.; van Leeuwen, P.; Rademacher, M. (2002), Evaluation trough literature data of the amount and amino acid composition of basal endogenous crude protein at the terminal ileum of pigs. A Anim. Feed Sci. Technol, 98, 49-60.

Johnston, L. J.; Noll, S.; Renteria, A.; Shurson, J. (2003), Feeding by-products high in concentration of fiber to nonruminants. In: $3^{\text {rd }}$ National Symposium On Alternative Feeds For Livestock And Poultry,
Kansas. Available in: www.wcroc.coafes.umn.edu. Acess on: 11 jan. 2005.

Kreuzer, M.; Hanneken, H.; Wittmann, M.; Gerdemann, M. M.; Machmüller, A. (2002), Effects of different fibre sources and fat addition on cholesterol and cholesterol-related lipids in blood serum, bile and body tissues of growing pigs. J. Anim. Physiol. Anim. Nutr., 86, 57-73.

Kreuzer, M.; Kirchgessner, M.; Roth, F. X. (1991), Experimental evaluation of the capacity of the hindgut of sows to ferment purified dietary ingredients and of consequences in nitrogen metabolism. In: Advances in animal physiology and animal nutrition, ed. Kirchgessner, M. Wageningen Pers: Wageningen, pp. 62-66.

Kyriazakis, I.; Emmans, G. C. (1995), The voluntary feed intake of pigs given feeds based on wheat bran, dried citrus pulp and grass meal, in relation to measurements of feed bulk. Br. J. Nutr., 74, 145. Abstract.

Lee, C. Y.; Lee, H. P.; Jeong, J. H.; Baik, K. H.; Jin, S. K.; Lee, J. H.; Sohnt, S. H. (2002), Effects of restricted feeding, low-energy diet, and implantation of trenbolone acetate plus estradiol on growth, carcass traits, and circulating concentrations of insulin-like growth factor (IGF)-I and IGF-binding protein -3 in finishing barrows. J. Anim. Sci., 80, 8493.

Ludwig, D. S.; Pereira, M. A.; Kroenke, C. H.; hilner, J. E.; Van Horn, L.; Slattery, M. L.; Jacobs, D. R.Jr. (1999), Dietary fiber, weight gain and cardiovascular disease risk factors in young adults. J. Amer. Med. Assoc., 282, 1539.

Matterson, L. D.; Potter, L. M.; Stutz, N. W.; Singsen, E. P. (1965), The metabolizable energy of feed ingredients for chickens. Res. Rep., 7, 3-11.

Nadai, A. (2003), Casca de arroz na restrição alimentar qualitativa para suínos em terminação. Monografia (Trabalho de Graduação em Zootecnia) - Faculdade de Ciências Agrárias e Veterinárias, Universidade Estadual Paulista, Jaboticabal.

National Research Council. (1998), Nutrient requirement of swine. 10. ed. Washington: National Academic Press, 190pp.

Penz Júnior, A. M.; Viola, E. S. (1998), Nutrição. In: Suinocultura Intensiva, ed. Sobestiansky, J. et al. Embrapa Cnpsa: Concórdia, pp. 45-64.

Polpa cítrica: opção econômica e segura para substituir o milho. Balde Branco, São Paulo, n. 409, 1998. Available in: www.bichoonline.com.br/artigos/bb00226.htm. Acess on: 8 jan. 2005.

Rostagno, H. S. Albino, L. F. T.; Donzele, J. L.; Gomes, P. C.; Oliveira, R. F.; Lopes, D. C.; Ferreira, A. S.; Barreto, S. L. T. (2005), Tabelas brasileiras para aves e suínos - Composição de alimentos $e$ exigências nutricionais. Imprensa Universitária/UFV: Viçosa. 
Statistical Analysis System Institute (Sas Institute). (1998), SAS user's guide. Statisic. SAS. Cary.

Silva, D. J., Queiroz, A. C. (2002), Análise de alimentos. Métodos químicos e biológicos. $3^{\text {rd }}$ ed. Imprensa Universitária/UFV: Viçosa.

Southgati, D.; Englyst, H. (1985), Dietary fibre: chemistry, physical properties and analysis. In: Dietary foods and disease, ed. Trowell, H.; Burkitt, D.; Heaton, K. Academic Press: London, pp. 31-55.

Stasse-Wolthuis, M.; Albers, H. F.; van Javeren, J. G.; Wil de Jong, J.; Hautvast, J. G.; Hermus, R. J.; Katan, M. B.; Brydon, W. G.; Eastwood, M. A. (1980), Influence of dietary fiber from vegetables and fruits, bran or citrus pectin on serum lipids, fecal lipids and colonic function. Amer. J. Clin. Nutr., 33, 1745-1755.
Van Soest, P. J.; Robertson, J. B.; Lewis, B. A. (1991), Methods for dietary fiber, neutral detergent fiber and non-starch polyssacharides in relation to animal nutrition. J. Dairy Sci., 74, 3583-3598.

Received: May 02, 2007; Revised: February 29, 2008; Accepted: June 22, 2009. 